\title{
Fit for purpose: Australia's National Fitness Campaign
}

\begin{abstract}
n January 1941, the Medical Journal of Australia
published an article on physical fitness that began with the words:

These are times when the term "physical fitness" is on almost everybody's lips, times when ability to live strenuous days, to do a man's work and more, is regarded as almost the summum bonum ["highest good" or "ultimate goal"] of life. ${ }^{1}$
\end{abstract}

Some 3 years earlier, the National Health and Medical Research Council (NHMRC) had listed the physical fitness of the nation among its priorities. The Chair at this time was Howard Cumpston, Australia's first DirectorGeneral of Health, who, at the Australasian Medical Congress in 1920, had spoken of his "dream of leading this young nation of ours to a paradise of physical perfection". ${ }^{2}$ Cumpston's concerns were focused on "preventable defects affecting the general health, the bodily fitness, and the national efficiency of a large part of the young people of this nation" ${ }^{3}$ The federal Minister for Health, William Hughes, shared these concerns, declaring in 1937 that Australians "could not leave to chance the development of their national health and physique". 4

It was feared that Australia was lagging behind other nations, especially European countries, in its encouragement of sport and physical training; Britain passed its Physical Training and Recreation Act in $1937 .{ }^{5}$ In November 1938, the NHMRC recommended the creation of a national council of physical fitness ${ }^{6}$ - a recommendation adopted shortly thereafter, and one which heralded the launch of the National Fitness Campaign.

Befitting the war stance of the country, the NHMRC proposed the promotion of physical fitness be "constantly linked with pride in the nation's achievements". ${ }^{6}$ By aiming to create a citizenry ready to defend the nation, focus was placed on the fitness of children. ${ }^{4}$ Yet this was not the first time the defence of the nation had been a motivation for improving the physical fitness of the youth of Australia. Before Federation in 1901, military drills had formed the basis for physical education in schools, and in 1909 a national cadet scheme had been introduced to improve the quality of physical training for boys, with the scheme lasting until $1931 .^{7}$

In order to give the National Fitness Campaign a statutory basis, the National Fitness Bill was introduced into federal Parliament in 1941. The then Minister for Health, Sir Frederick Stewart, argued that, although

this is a machine age and a time of mechanised warfare ... behind the machine, in the shop or on the battlefield, there must be a fit people ... and provision, above all, to ensure the continued fitness of the young folk to whom we will hand on that heritage for which we are now fighting. ${ }^{8}$

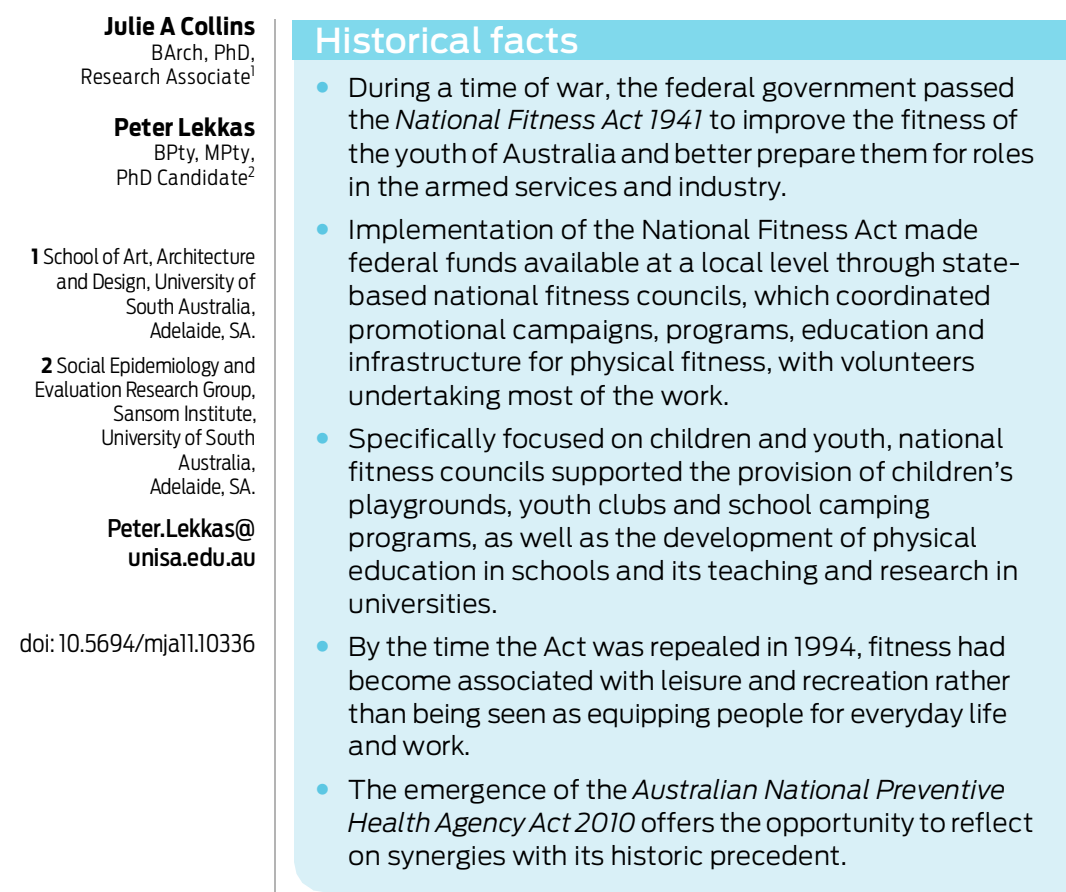

The Bill received support from all sides of politics and the National Fitness Act 1941 was assented to on 4 July of that year. ${ }^{9}$

The aims of the National Fitness Act were to promote an appreciation of and engagement in physical fitness. It endeavoured to achieve this by establishing a fund from which monies were distributed to newly formed statebased national fitness councils, as well as state education departments and universities. This decentralised approach allowed the federal government to engage both state administrators and local communities. The national fitness councils coordinated promotional campaigns, programs and infrastructure grants in communities, with volunteers undertaking most of the work. State education departments were given funding to train teachers in physical education, purchase equipment and develop school camping programs. Grants were also provided to university departments of physical education to assist in the training of physical education specialists.

An early example of the output of the national fitness councils was The 1941 keep fit book, produced and distributed by the National Fitness Council of South Australia (Box). ${ }^{10}$ This was a pocket-sized booklet in which health was expressed as being "more than mere freedom from disease; it is something positive: it gives a sense of vitality and strength - of real joy in living" ${ }^{10}$ The book recommended a well balanced diet, enjoyable activity in the sunlight and fresh air, sufficient sleep and rest, attention to personal hygiene, and regular medical and dental examinations. Also highlighted were exercises 


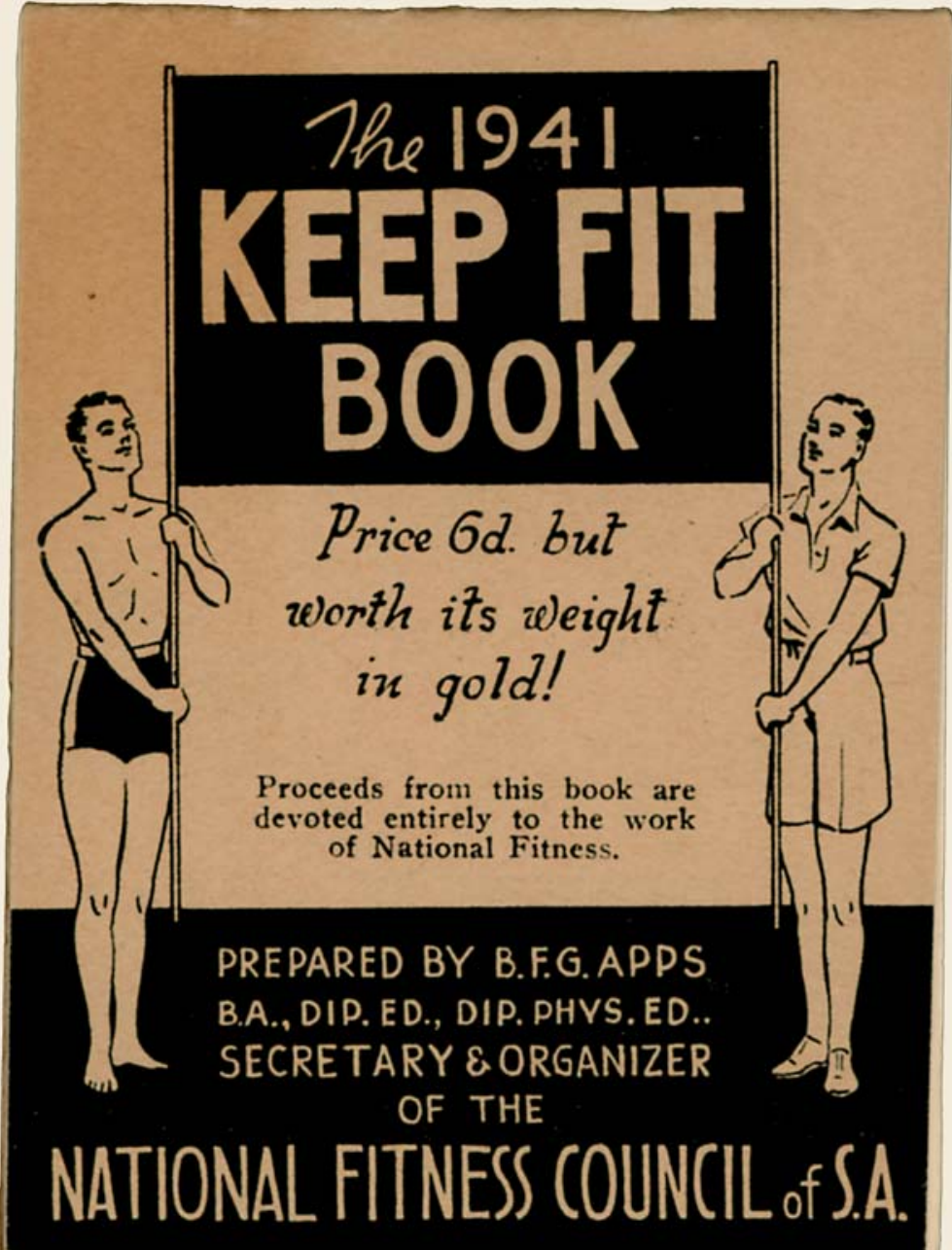

The 1941 keep fit book, National Fitness Council of South Australia. Courtesy: State Library of South Australia.

designed to develop good posture; stimulate the normal functioning of the heart, lungs, liver, intestines and muscles; and "counteract the artificial activities that make up the daily routines for most of us: for instance, driving in cars and sitting at desks". ${ }^{10}$

Heeding widespread calls for investment in civic infrastructure for young children, ${ }^{11,12}$ the national fitness councils served as strong advocates for playgrounds. Assistance in developing these was directed through small grants auspiced by state-based playgrounds associations. Guidance in playground design was provided in the form of Children's playgrounds, a publication distributed to local councils throughout Australia in $1944 .{ }^{13}$ In this,

playgrounds were defined as "a healthy and safe environment within easy distance of homes, especially reserved for the leisure hours of children" and, in the foreword by Cumpston, described as "one of the least expensive and one of the most valuable means of improving the general state of physical fitness of the community" ${ }^{13}$ Play equipment was recommended to cultivate confidence, muscular strength, coordination and skill, while open spaces were intended to foster social interaction and team games. Critically, the guidelines suggested the site and design of playgrounds be grounded within the local context, with input sought from a multidisciplinary team encompassing, among others, the local medical officers, district health inspector and a landscape architect. $^{13}$

Evolving over time, the focus of national fitness councils broadened to encompass the emerging demographic category of the teenager. To this end, the councils supported the establishment of youth clubs and development of advanced experiential activities, namely rock climbing, bushwalking and camping. Adults were also targeted, particularly those over the age of 30 years, with Prime Minister Harold Holt launching the "Fitness Australia" campaign in 1967, which had as one of its outcomes the establishment of jogging groups across the country. ${ }^{14}$

After more than 50 years in existence, the National Fitness Act was repealed by the Environment, Sport and Territories Legislation Amendment Act 1994 (Cwlth). ${ }^{9}$ This reflected an earlier change, in 1972, when responsibility for national fitness shifted from the Department of Health to the newly created Department of Tourism and Recreation, and the commensurate transfer of control of the national fitness councils to state government departments of recreation. As a result, the National Fitness Act fell into disuse, and the national fitness councils were phased out during the 1970s. ${ }^{15}$

During its time, the National Fitness Act functioned to promote and enable a fit and healthy citizenry. However, it is difficult to gauge its success, as evaluations of initiatives were limited. Annual reports were delivered to federal Parliament, but proxy measures such as gross participation rates were, in general, employed as evidence of impact on the nation's fitness. Compounding this evidence gap, contemporary analyses of the period preceding the repeal of the Act have highlighted an increase in prevalence of overweight and obesity among children and young people. ${ }^{16,17}$ Although these observations may serve to question the Act's influence, this simplistic interpretation is questionable if for no other reason than that it ignores the social, technological and environmental transformations of the mid to late 20th century. ${ }^{18}$

Beyond metrics of fitness, the Act's legacy is more tangible. It provided crucial material resources and infrastructure in local communities. Perhaps more importantly, the Act nurtured the emergence of physical education, recreation and sports medicine bodies, including the Australian Council for Health, Physical Education and Recreation and the Australian Sports Medicine Association (now Sports Medicine Australia). Indelible also was the provision in the Act for research by the NHMRC into causes of physical unfitness. ${ }^{9}$

In its governance, design, application and rhetoric, the Act was strikingly modern. While authority of the Act resided with the Department of Health, the department cooperated with departments of labour and national service and, at a state level, education. With the Act commanding a position federally while engaging across multiple levels - national, regional and local — fitness was afforded a prominence to which current health 
initiatives aspire. ${ }^{19}$ Significantly, the Act embraced a vision of fitness, and therein public health, that acknowledged the role of supportive environments, community engagement and development of personal skills — facets synonymous with the Ottawa Charter for Health Promotion of $1986 .{ }^{20}$ Its definitions of health and fitness were also congruent with the Ottawa Charter, as evidenced by Minister for Health Sir Fredrick Stewart stating in 1941, "Whilst we are now preoccupied with national fitness to survive, we cannot forget the ultimate goal of fitness [is in order] to enjoy [life]". ${ }^{8}$

Given the recent emergence of the Australian National Preventive Health Agency Act 2010, ${ }^{21}$ reflections on historic precedents are salient. ${ }^{22}$ In focus and application, there are synergies between the Acts of the past and present. Obvious among these is the prominence afforded to the promotion of physical activity, although it has been framed differently by the two Acts: as a means to fitness formerly, and now as part of a broader, more holistic, healthy lifestyle. Parallels between the Acts are also visible in their attention to the development of an appropriate workforce, the establishment of a research agenda, and the implementation of approaches in various settings to account for the multilevel influences that shape healthful behaviour.

However, despite these similarities, it is difficult here to see how well the past informs the present because of the fragmented evidence base for the impact of the National Fitness Act - and this is perhaps the most relevant lesson. Recognition of this knowledge gap substantiates the need to effectively evaluate interventions to be implemented under the new Act. While conceding the known difficulties in evaluating complex social interventions, guidance for this type of evaluation does exist ${ }^{23,24}$ - and evaluation is acknowledged as being of equal importance as the initiatives themselves.

Competing interests: No relevant disclosures.

1 Physical fitness and its determination [editorial]. Med J Aust 1941; 1: 117-118.

2 Roe M.Cumpston, John Howard Lidgett (1880-1954). In: Serle G, Nairn B, editors. Australian dictionary of biography. Volume 8. Melbourne: Melbourne University Press, 1981: 174-176.
3 Cumpston JHL. The health of the people: a study in federalism. Canberra: Roebuck, 1978: 78.

4 Recreation - Campaign for national fitness. Sydney Morning Herald 1937; 3 Jul: 22. http://trove.nla.gov.au/ndp/del/article/17392799 (accessed Nov 2011)

5 Zweiniger-Bargielowska I. Building a British superman: physical culture in interwar Britain. J Contemp Hist 2006; 41: 595-610.

6 Lewis MJ. Editor's introduction. In: Cumpston JHL. Health and disease in Australia: a history. Canberra: AGPS, 1989: 15.

7 Fischer I. The involvement of the Commonwealth Government in physical education: from defence to national fitness. In: Cashman R, O'Hara J, Honey A, editors. Sport, federation, nation. Sydney: Walla Walla Press, 2001.

8 National fitness - University co-operation. Cairns Post 1941; 2 Jul: 8. http://trove.nla.gov.au/ndp/del/article/42292055 (accessed Nov 2011).

9 National Fitness Act 1941. Repealed by Environment, Sport and Territories Legislation Amendment Act 1994 (Cwlth). http://www.comlaw.gov.au/ Details/C2004C05483 (accessed Jul 2011). fitness was

afforded a

prominence to

which current

health

initiatives

aspire
10 Apps BFG. The 1941 keep fit book. Adelaide: National Fitness Council of SA, 1941.

11 Bunning WR. Homes in the sun: the past, present and future of Australian housing. Sydney: WJ Nesbit, 1945.

12 Collins J, Lustri S, Bird L, Garnaut C. Civic spaces for children: playground design in twentieth century South Australia. J Hist Soc South Aust 2010; 38: 73-92.

13 Apps BFG. Children's playgrounds. Canberra: Department of Health, 1944.

14 Department of Health, Commonwealth Council for National Fitness. National fitness, Australia: report of the activities carried out under the Commonwealth National Fitness Act 1941. Canberra: AGPS, 1969.

15 Simpson AE. The National Fitness Council of South Australia: a history 19391976. Adelaide: Department of Recreation and Sport, 1986.

16 Magarey AM, Daniels LA, Boulton TJ. Prevalence of overweight and obesity in Australian children and adolescents: reassessment of 1985 and 1995 data against new standard international definitions. Med J Aust 2001; 174: 561-564. (Erratum in: Med J Aust 2001; 175: 392.)

17 Olds TS, Tomkinson GR, Ferrar KE, Maher CA. Trends in the prevalence of childhood overweight and obesity in Australia between 1985 and 2008. Int J Obes (Lond) 2010; 34: 57-66.

18 Olds TS, Harten NR. One hundred years of growth: the evolution of height, mass, and body composition in Australian children, 1899-1999. Hum Biol 2001; 73: 727-738.

19 World Health Organization, Government of South Australia. Adelaide Statement on Health in All Policies: moving towards a shared governance for health and well-being. Adelaide: World Health Organization, 2010.

20 World Health Organization. Ottawa Charter for Health Promotion. Geneva: WHO, 1986. http://www.who.int/healthpromotion/conferences/previous/ ottawa/en/ (accessed Nov 2011)

21 Australian National Preventive Health Agency Act 2010. http://www.austlii. edu.au/au/legis/cth/num_act/anphaa2010428.txt (accessed Jul 2011).

22 Szreter S. History, policy and the social history of medicine. Soc Hist Med 2009; 22: 235-244.

23 Craig P, Dieppe P, Macintyre S, et al. Developing and evaluating complex interventions: new guidance. London: Medical Research Council, 2008.

24 Green LW, Kreuter MW. Health program planning: an educational and ecological approach. 4th ed. New York: McGraw-Hill, 2005. 